\title{
NEW INSIGHTS CONCERNING IDENTIFICATION, MANAGEMENT AND CONSERVATION OF INDIGENOUS TREES AND SHRUBS IN THE NETHERLANDS
}

\author{
Norbertus Cornelis Maria MAES \\ Ecologisch Adviesbureau Maes, Achter Clarenburg 2, NL-3511JJ Utrecht, Netherlands \\ e-mail: maes.dool@planet.nl
}

\begin{abstract}
In densely populated European countries like the Netherlands, old landscape elements such as ancient woodlands and ancient hedges are today rare. Owing to the introduction of exotic species and indigenous trees and shrubs imported from other climate zones, recognition of truly wild, i.e. autochthonous, individuals and populations is now problematical, posing challenges for forest management agencies, particularly at Natura 2000 sites. The author has developed a method for recognising genetically pure wild woody species, based on characteristics of the plant itself and those of the growing site. With this method, explained here, around $70 \%$ of the Netherlands has been surveyed, along with much of Flanders and part of the lower Rhine region of Germany. The results are illustrated with reference to two Dutch ancient woodlands, where new insights were obtained in terms of native status of the woody species and the 'authenticity' of the tree and shrub layer.
\end{abstract}

Keywords: ancient woodlands, conservation status, genetic recognition, green landscape heritage, living gene bank, mapping, naturalness

\section{Introduction}

This paper seeks to contribute to our knowledge of natural woodlands in the densely populated countries of Europe. Such woodlands are now rare and often comprise a heterogeneous mix of originally wild trees and shrubs, trees and shrubs planted by forestry agencies, ornamental species, berry-bearing cultivars introduced by birds, and wind-sown woody species. In this paper the term 'species' is generally used loosely to include hybrids, subspecies and varieties. For botanists engaged in surveys and suchlike, the observed tree and shrub layers pose analytical problems and, partly in consequence, are frequently ignored as being irrelevant.

There is still few scientific literature addressing these issues, even though improved knowledge of wild trees and shrubs is important for two reasons: for floristics and vegetation science, and for improved forest management.

In this context the author has developed a methodology for distinguishing truly wild trees and shrubs from their non-wild counterparts in the field, using the characteristics and criteria of the woody species itself and those of its growing site. This paper explains the methodology and illustrates its use with reference to two ancient woodlands in the Netherlands.

First, though, I provide a brief historical review of Dutch forests and woodland in the context of a densely populated, highly fragmented landscape. This is followed by a section on terminology. I then explain the methodology itself, its use over a period of 30 years, and the results it has yielded. This includes a comprehensive review of the current status of most of the 
Netherlands' autochthonous tree and shrub species. There follows a description of how the methodology has been applied in two particular areas of ancient woodland. The paper concludes with some recommendations for improved management of ancient woodlands.

\section{Forestry in the Netherlands}

The Netherlands is a small, densely populated $\left(41,500 \mathrm{~km}^{2}\right.$, approx. 17 million people), industrialised country that is very intensively farmed. By medieval times its forests had already been decimated as land was drained for agriculture and habitation, especially in the marshy west of the country. The last truly primeval forest vanished many centuries ago. At present there is approx. 96,000 ha of forest and woodland, of which less than $5 \%$ can be classed as 'ancient woodland'. At a rough estimate, of the ancient woodland still extant around 1900, less than 10\% has been preserved. Although most of this woodland now enjoys statutory protection, this is not the case for indigenous woody species, of which there are around 100 in the Netherlands. About half of these are currently vulnerable or threatened, with four now probably nationally extinct [7]. The list of nationally protected plants features just two woody species: mezereon (Daphne mezereum) and common juniper (Juniperus communis) [12]. The national Red List includes ca. 20 woody species, most of them dwarf shrubs [12].

Dutch forests are managed in a wide variety of ways, both traditional and experimental, including grazing, coppicing, thinning and 'hands-off' management (i.e. leaving nature to itself). It is virtually never the case, however, that management is focused on the woody species that in fact constitute the backbone of the forest biocoenosis.

Given the Netherlands position on the European continent, almost all the tree and shrub species have an extensive range to the south, a favourable situation in view of climate change. If populations are too small, though, they become vulnerable, and such is the case today.

Large-scale forestry and farming has led to ongoing loss of ancient forest remnants and old hedgerows, particularly in the late $19^{\text {th }}$ and $20^{\text {th }}$ century. Nonetheless, there still remain a few highvalue, though modestly-sized ancient woodlands, hedgerows and wooded banks as relic woodland ecosystems with indigenous trees and shrubs. Here in the Low Countries these indeed represent the main sources of regional biodiversity. Most are protected as nature reserves, with the largest classed as Natura 2000 areas under European legislation. A few are located on farmland. Over the past thirty years around $70 \%$ of these source areas and the wild tree and shrub populations in the Netherlands have been mapped and surveyed [6], and the results put online for interested parties to consult (https://rce.webgispublisher.n1/Viewer.aspx?map=groen\%5Ferfgoed). The Atlas of the Netherlands' Green Landscape Heritage (Fig. 1), published by the Netherlands Cultural Heritage Agency, was compiled using a methodology developed in the field and subsequently documented (in Dutch) by the author and his ecological consultancy in collaboration with several allied agencies $[6,8]$. This methodology is outlined below.

Conservation of these genetic resources in the Netherlands, as well as in neighbouring countries, is proving no easy task. Nonetheless, as an EU Member State, the Netherlands has an obligation to meet its Natura 2000 requirements and the terms of internationally ratified treaties on biodiversity and the protection of wild plants and animals.

Exotic, indigenous and autochthonous

The aim of the Natura 2000 programme and other conservation efforts is to preserve wild flora and fauna, and thus also wild trees and shrubs. In this context the term 'wild' means trees and 
shrubs that spontaneously moved into our region from southern Europe after the last Ice Age. DNA studies have shown, for example, that our indigenous pedunculate oak (Quercus robur) and sessile oak (Quercus petraea) migrated here from Spain and Italy, respectively, bringing with them the ecosystems in which these trees flourish $[14,1]$.

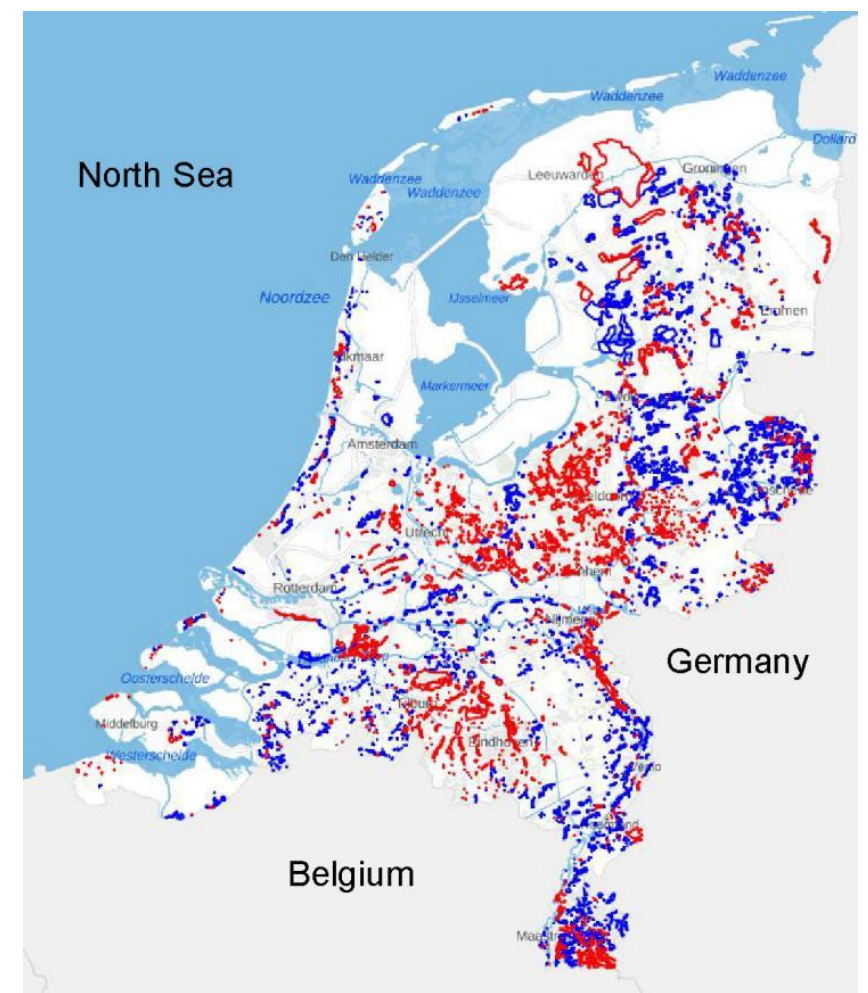

Fig. 1: Map of 'Green Landscape Heritage' (Kaart groen erfgoed) in the Netherlands. In red are represented the landscape elements mapped in the field. In blue are indicated landscape elements not surveyed in the field but very likely hosting autochthonous trees and shrubs, based on the study of old maps (from Maes, 2016).

Over the centuries the Dutch countryside has been so thoroughly transformed that recognizing landscape elements comprising wild trees and shrubs is by no means straightforward. Most forests, wooded banks and hedgerows are modest in size or length and are moreover exposed to a wide range of external influences. Soils are affected by fertilizers and farm chemicals, for example, while the seeds of non-native species of trees and shrubs are brought in by birds from parks and gardens. Particularly since around 1950, exotic species have been extensively planted across the country and, more importantly in our present context, non-wild indigenous trees and shrubs imported from other European flora districts. The latter cause considerable confusion in the field because of their close resemblance to the wild, i.e. autochthonous, specimens truly native to the Netherlands, but they differ genetically and in many cases morphologically, too. They can often be assigned to different subspecies or varieties.

In the Low Countries, even forests regarded as 'natural' rarely comprise solely autochthonous trees and shrubs. On the one hand, harvesting timber from natural forests and replanting of harvestable trees was long deemed de rigueur, while on the other hand there was, and still is, no legal requirement for autochthonous planting stock to be used. Conservation agencies, for their part, had not properly thought through the consequences of planting decisions. All too 
readily it was assumed that a self-sustaining forest vegetation would emerge naturally from a modest basket of initial measures. History has shown, though, that 'hands-off' management in fact leads to a decline in biodiversity. To preserve our remaining ecological values, including trees and shrubs, requires sustainable forms of conservation management.

\section{Key terms}

There is frequent terminological confusion when it comes to the ecological status of woody species in a given region or country. Some of the key terms are as follows:

Indigenous (native): refers to a species growing in its natural distribution, or natural range. Autochthonous (wild): refers to an indigenous species that arrived here after the last Ice Age and has been naturally rejuvenating since. If planted, must be of strictly local autochthonous stock.

Exotic: refers to a species introduced by man, either directly or indirectly, to an area where it does not occur naturally.

Spontaneous: refers to a plant deriving from seed from existing populations or individuals, whether native, wild or exotic.

Naturalised: refers to a non-wild species now established, whether or not spontaneously, outside its natural range and spontaneously reproducing and maintaining a presence.

Archeophyte: a species naturalised prior to 1500, such as wild medlar (Mespilus germanicus) in the Netherlands.

\section{A science-based methodology for distinguishing wild from non-wild trees and shrubs}

In a densely populated country like the Netherlands, specialist knowledge and methodology are essential if the conservation values embodied in our autochthonous trees and shrubs are to be preserved and improved. This is why in 1990 the then-Ministry of Agriculture, Nature Management and Fisheries initiated a project to review the genetic quality of the country's indigenous woody species $[7,10]$. One element of this effort was to develop a methodology for determining whether or not an indigenous tree or shrub is autochthonous (see text box), using two sets of criteria: relating to the tree or shrub itself, and to the habitat where it is growing.

\section{Criteria regarding the tree or shrub itself}

- Indigenous in the Netherlands and lying within the species' natural range.

- Not or rarely commercially available and seldom if ever planted; e.g. crab apple (Malus sylvestris), midland hawthorn (Crataegus laevigata), European white-elm (Ulmus laevis).

- Not a cultivar.

- Not showing anomalous morphology indicating a different climatic zone.

- Exhibiting signs of traditional management (e.g. coppicing, pollarding, singling; see Fig. 2).

2. Criteria regarding the habitat

- The woodland or hedgerow is marked on an ordinance survey map from around 1850. The same may sometimes also hold for individual trees, along fields, for example.

- The vegetation in and around the woodland or hedgerow adequately matches the type appropriate for the tree or shrub.

- The soil is in line with the vegetation type and is more or less undisturbed. 
- The herb layer includes indicators of ancient woodland such as wood anemone (Anemone nemorosa), herb paris (Paris quadrifolia), hairy wood-rush (Luzula pilosa) and bracken (Pteridium aquilinum).

- The landscape as a whole shows clear signs of being traditionally managed.

- The surrounding countryside has historical landscape features like hedgerows, meandering streams and irregular field boundaries.

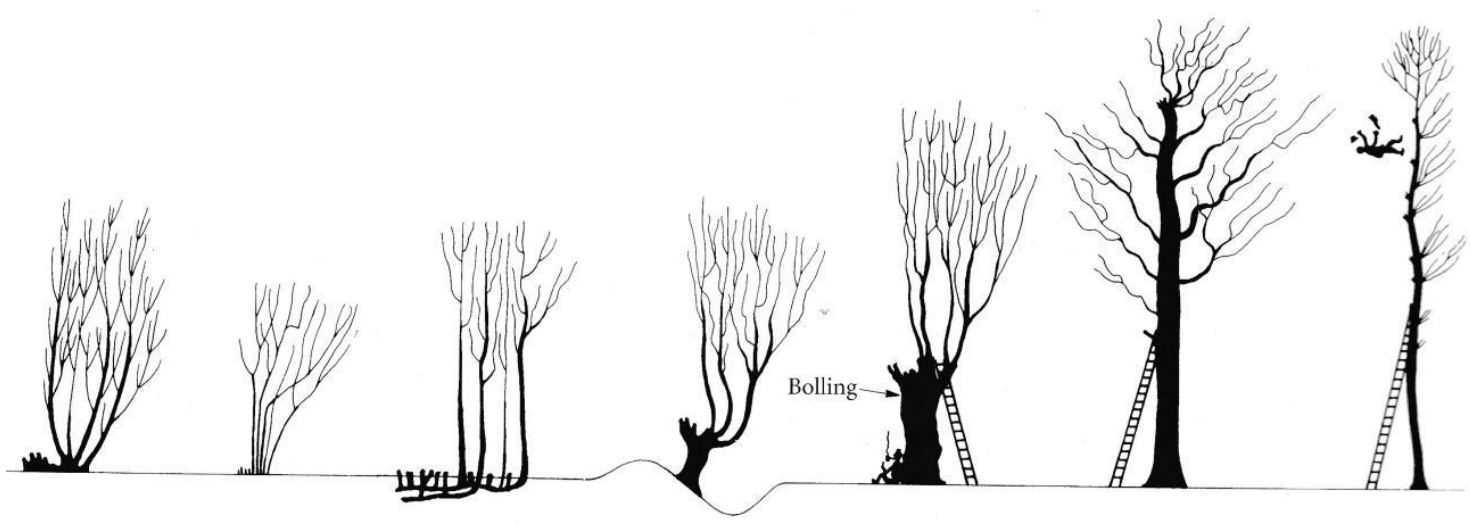

Fig. 2: Examples of different forms of traditional tree coppicing or pruning (from Rackham 2003) [17].

Valuable additional information may be gleaned from archives, interviews with local inhabitants and, increasingly, through archaeobotanical and genetic studies $[4,5,13]$. In the Netherlands, for example, there is documentation of crab apple trees enjoying protection in the 16th and 17th centuries; pips of crab apples and wild pears (Pyrus pyraster) have been recovered in a Neolithic context, providing unambiguous evidence of their indigenous status; yew (Taxus baccata), wayfaring tree (Viburnum lantana) and common juniper have likewise been found in a prehistoric context [7]. Conversely, there are no finds of wild cherry (Prunus avium), giving rise to doubts as to its indigenous status.

Thanks to the availability of reference populations from our field study, supplementary DNA studies on species including crab apple, small-leaved elm (Ulmus minor), European whiteelm, oaks (Quercus spp.) and limes (Tilia spp.) mean the autochthonous status of individuals and populations can now be established with growing certainty.

Rarely are all the cited criteria satisfied, though. At impoverished sites herb-layer indicators may be absent, for example, while old ordinance survey maps may be insufficiently detailed.

A good starting point for practical fieldwork are the earliest national ordinance survey maps, dating back in the Netherlands to around 1850. If the woodland or hedgerow being surveyed is marked on the map, the other criteria should be checked in the field: taxonomic characters, signs of traditional forest management like coppicing, soil characteristics, presence of ancient-woodland indicators in the herb layer and so on.

Clearly, it will not always be feasible to assign every hazel (Corylus avellana), common hawthorn (Crataegus monogyna) or red dogwood (Cornus sanguinea) with absolute genetic certainty to the truly wild flora of a region. For that reason the methodology uses a three-part scheme: 'almost certainly autochthonous', 'probably autochthonous' and 'potentially autochthonous'. Beside that we use: "definitely not autochthonous" (planted) and spontaneous. 


\section{Results of the fieldwork (1990-2020)}

Over the past thirty years this methodology has been employed in detailed fieldwork to survey around $70 \%$ of the Netherlands' wooded stands, i.e. ancient woodlands, ancient hedges, wooded banks, old thickets and, to a lesser degree, free-standing trees (Fig. 3). Since 2016 the results of our fieldwork and study have been available online in the 'Atlas of the Netherlands' Green Landscape Keritage' [6].

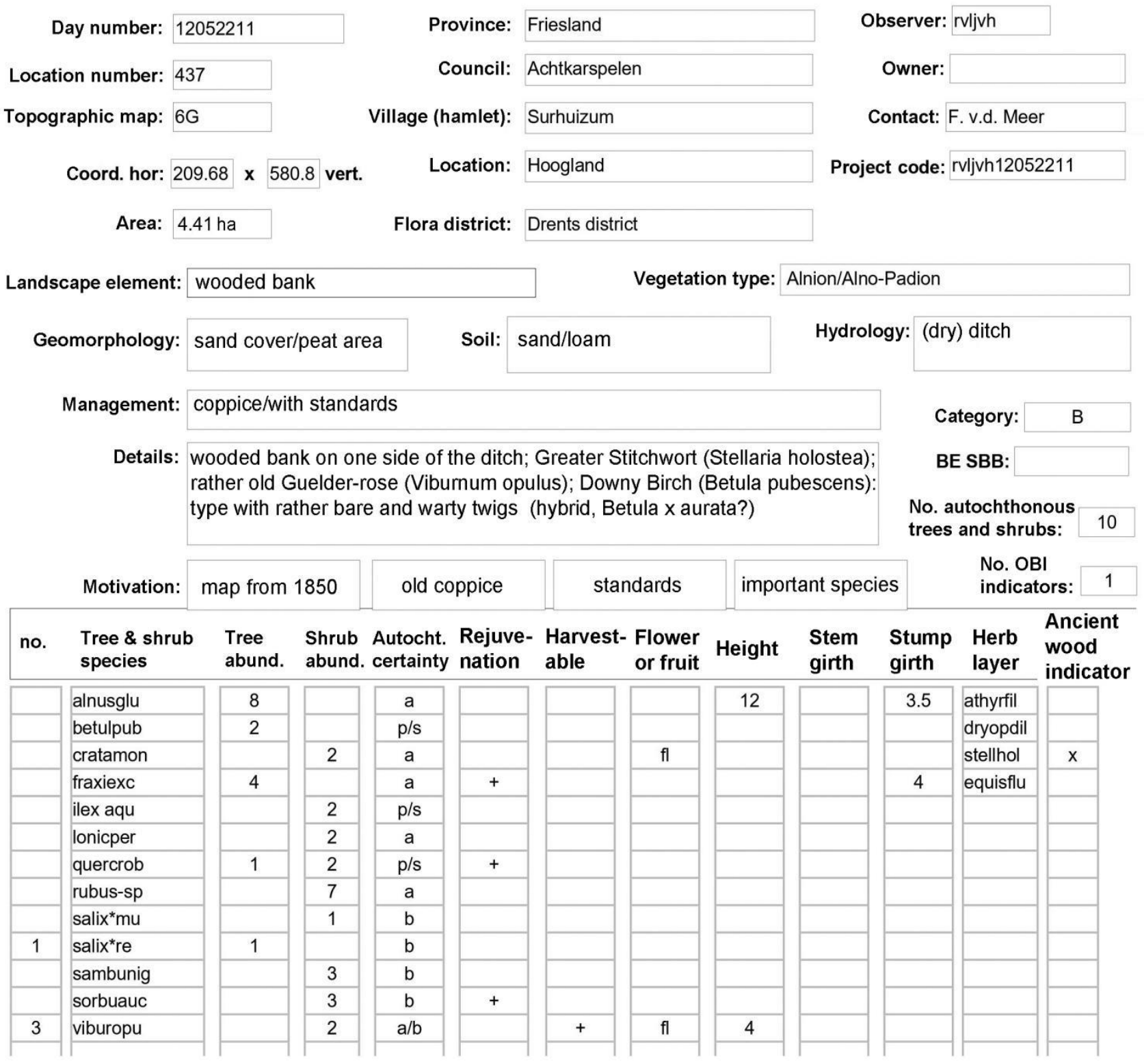

Fig. 3: Example of a specially designed form used for filling in the field observations

This Atlas (see above) shows the landscape elements surveyed, with their historicalgeographical context, and provides information on the tree and shrub species found, historical management and historical geography, as well as a cultural-historical and ecological valuation (on a scale A to C).

Parallel work has been done in the Flemish part of Belgium [11] and a small portion of neighbouring Germany (North-Rhine Westphalia). Like the Netherlands, these are heavily built- 
up regions characterized by widespread planting of non-autochthonous woody stock. In other countries, surveys of this kind are rare. In a number of German states, gene banks of autochthonous species are being established. Unfortunately, though, the term 'autochthonous' has in part been abandoned there since 2003 and replaced by 'gebietseigen': literally 'area-specific', and ambiguous vis-à-vis the distinction between 'native' and 'autochthonous' [3]. In the present paper we are concerned, though, with the next step: from 'indigenous' to 'autochthonous'.

From our fieldwork and supplementary studies we can conclude that the Netherlands is home to around one hundred indigenous species of trees and shrubs (including dwarf shrubs and excluding the more than 200 bramble species), i.e. individual specimens and populations that can be taken as belonging to the wild flora. We were surprised to find a number of species that had not been anticipated, certainly at the regional level, including wild pear, European white-elm and several wild roses (Rosa spp.) At the same time, though, four species emerged as nationally extinct and many more at the provincial level.

Our survey, over a period of 30 years, allows us to report here in tabular form the most vulnerable species in the Netherlands (excluding dwarf shrubs and brambles) and their current status in each province (Table 1).

One striking result is that species that in themselves are a common sight, like beech (Fagus sylvatica) and sycamore (Acer pseudoplatanus) are rare as autochthonous specimens and may locally even be threatened with extinction. In the case of certain hybrids, one of the parent species proved to be extinct, or almost so, though the hybrid itself remains very viable and has indeed stabilized. This holds, for example, for the crosses between large-sepalled and midland hawthorn (Cratagus x macrocarpa: C. rhipidophylla x laevigata) and between small-leaved and large-leaved lime (Tilia $\mathrm{x}$ europaea: T. cordata $\mathrm{x}$ platyphyllos). Of the approximately one hundred indigenous tree and shrub species, around half (!) are now known to be rare to very rare, with a number even facing possible local extinction. Large-sepalled hawthorn (Crataegus rhipidophylla), Scots pine (Pinus sylvestris), wayfaring tree (Viburnum lantana) and almond willow (Salix triandra) are already extinct throughout the Netherlands, while remaining populations of species like wedgeleaved rose (Rosa elliptica), cornelian cherry (Cornus mas) and wild pear now comprise less than twenty individuals. With certain other species like small-leaved lime (Tilia cordata), Sherard's downy-rose (Rosa sherardii), mezereon (Daphne mezereum), crab apple (Malus sylvestris), European white elm (Ulmus laevis) and yew only a handful of sites remain.

As the Table 1 shows, at the regional level many indigenous species are classed as vulnerable or seriously threatened with extinction. At the landscape level, the total relic ancient woodland and hedgerows with autochthonous indigenous trees and shrubs is estimated at below $3 \%$ of the total area of woodland, wooded banks, thicket and hedgerows. The main drivers of this massive loss are ongoing urbanization (around both towns and villages), road-building, intensivefarming impacts, large-scale drainage and wide use of planting stock from other European climate zones. Another key factor is that management of natural woodland is scarcely if ever geared to conserving wild indigenous trees and shrubs in situ. In natural woodland, including areas under Natura 2000 protection, there are no requirements regarding conservation and planting of autochthonous woody species, with the sole emphasis on the fauna, the herb layer and 'process objectives'. 
Greater focus on native trees and shrubs: recent developments

Given the major decline in populations of native woody species, in recent years there has thankfully been an upsurge in interest in the Netherlands' natural heritage of trees and shrubs. Prior to forest stands being thinned, for example, surveys identifying characteristic woody species are now often consulted so individuals or populations in question can be spared. Another key development has been the creation in 2006 of a living gene bank of autochthonous trees and shrubs, following the example of several German states, which now comprises some 70 indigenous woody species of diverse regional provenance (Fig. 4).

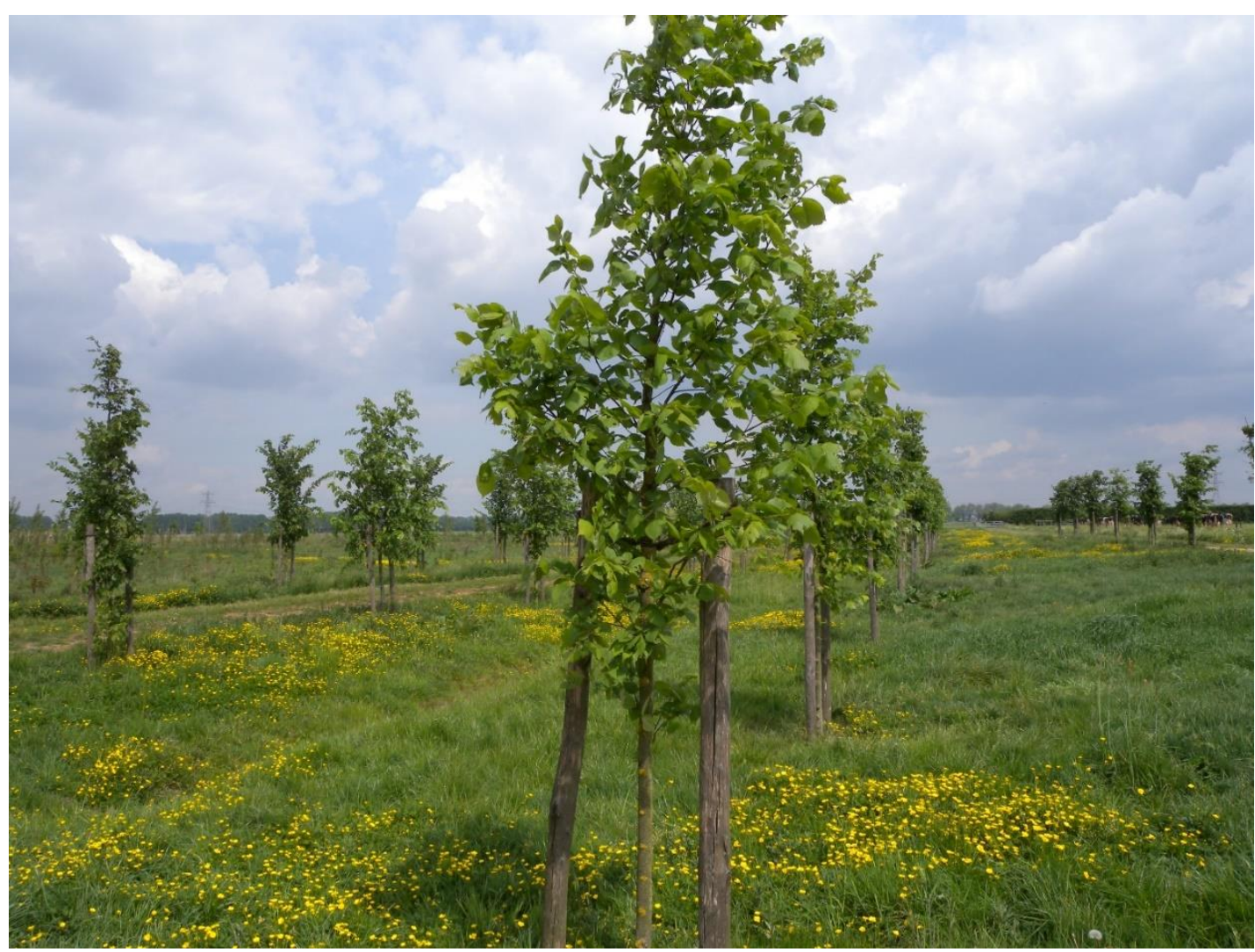

Fig. 4: Planted saplings of European white-elm (Ulmus laevis) in the National Living Gene Bank

This Autochthonous Gene Bank, set up and managed by the National Forestry Commission (Staatsbosbeheer), operates under the specialist guidance of the Dutch Centre of Genetic Resources (Centrum voor Genetische Bronnen in Nederland). The institute conducts research into genetic characteristics and reliability. Certified autochthonous stock is cultivated from seeds and cuttings sourced from Van Loon Ecological Consultancy (Ecologisch Adviesbureau Van Loon) and in the past from BRONNEN: (former) Native Tree and Shrub Centre and collected using the data yielded by our surveys $[6,7]$. Today, this autochthonous planting stock is being used ever more widely. Over and against this progress, though, conservation and management of autochthonous trees and shrubs in situ is still proving problematic. 
Table 1: Vulnerable tree and shrub species in terms of rarity within the Dutch provinces (Gr: Groningen, Fr: Friesland, Dr: Drenthe, Ov: Overijssel, Ge: Gelderland, NH: Noord-Holland, ZH: Zuid-Holland, Ut: Utrecht, Ze: Zeeland, NB: Noord-Brabant, Li: Limburg; the province Flevoland, created by drainage of an inland sea, is not included). Symbols: $\mathrm{x}$ : quite rare; $\mathrm{xx}$ : rare; $\mathrm{xxx}$ : very rare; ?: uncertain

\begin{tabular}{|c|c|c|c|c|c|c|c|c|c|c|c|c|}
\hline Scientific name & Common name (hybrid's parent species) & $\mathbf{G r}$ & $\mathbf{F r}$ & Dr & Ov & Ge & NH & $\mathbf{Z H}$ & $\mathbf{U t}$ & $\mathbf{Z e}$ & NB & $\mathbf{L i}$ \\
\hline Acer campestre & field maple & & & & $\mathrm{xxx}$ & $\mathrm{xxx}$ & & & & & $\mathrm{xx}$ & $\mathrm{xx}$ \\
\hline Acer pseudoplatanus & sycamore & & & & & & & & & & & $\mathrm{xx}$ \\
\hline Berberis vulgaris & barberry & & & & & $\mathrm{xxx}$ & $\mathrm{x}$ & $\mathrm{x}$ & & & & $\mathrm{xxx}$ \\
\hline Cornus mas & cornelian cherry & & & & & & & & & & & $\mathrm{xxx}$ \\
\hline Crategus laevigata & midland hawthorn & $\mathrm{xxx}$ & $\mathrm{xxx}$ & $\mathrm{xx}$ & $\mathrm{x}$ & $\mathrm{x}$ & & $\mathrm{xxx}$ & $\mathrm{xxx}$ & & $\mathrm{x}$ & $\mathrm{x}$ \\
\hline Crataegus x macrocarpa & Crataegus laevigata x C. rhipidophylla & $\mathrm{xxx}$ & & $\mathrm{xx}$ & $\mathrm{xxx}$ & $\mathrm{xxx}$ & & & & & $\mathrm{xxx}$ & $\mathrm{xxx}$ \\
\hline Crataegus x subsphaerica & Crataegus monogyna x C. rhipidophylla & $\mathrm{xxx}$ & $\mathrm{xxx}$ & $\mathrm{xxx}$ & $\mathrm{xxx}$ & $\mathrm{xxx}$ & & & $\mathrm{xxx}$ & & $\mathrm{xxx}$ & $\mathrm{xxx}$ \\
\hline Daphne mezereum & mezereon & & & & $\mathrm{xxx}$ & & & & & & & $\mathrm{xxx}$ \\
\hline Fagus sylvatica & beech & & & $\mathrm{xxx}$ & $\mathrm{xxx}$ & $\mathrm{x}$ & $\mathrm{xxx}$ & & $\mathrm{xxx}$ & & & $\mathrm{xx}$ \\
\hline Juniperus communis & juniper & & $\mathrm{xxx}$ & $\mathrm{xx}$ & $\mathrm{xx}$ & $\mathrm{xx}$ & $\mathrm{xxx}$ & & $\mathrm{xxx}$ & & $\mathrm{xxx}$ & $\mathrm{xxx}$ \\
\hline Ligustrum vulgare & wild privet & & & & & $?$ & $\mathrm{x}$ & $\mathrm{x}$ & & & & $\mathrm{x}$ \\
\hline Lonicera xylosteum & fly honeysuckle & & & & & & & & & & & $\mathrm{xxx}$ \\
\hline Malus sylvestris & crab apple & & & $\mathrm{xxx}$ & & $\mathrm{xxx}$ & & & & & & $\mathrm{xxx}$ \\
\hline Pinus sylvestris & Scots pine & & & & & $?$ & & & & & & \\
\hline Populus nigra & black poplar & & & & $\mathrm{xxx}$ & $\mathrm{xx}$ & $\mathrm{xxx}$ & $\mathrm{xxx}$ & & & $\mathrm{xxx}$ & $\mathrm{xxx}$ \\
\hline Pyrus pyraster & wild pear & & & & $\mathrm{xxx}$ & $\mathrm{xxx}$ & & & & & & \\
\hline Quercus petraea & sessile oak & & & $?$ & $\mathrm{xxx}$ & $\mathrm{x}$ & & & $\mathrm{xx}$ & & & $\mathrm{x}$ \\
\hline Rhamnus cathartica & buckthorn & $\mathrm{xxx}$ ? & & $\mathrm{xxx}$ & $\mathrm{xx}$ & $\mathrm{xx}$ & $\mathrm{x}$ & $\mathrm{x}$ & $\mathrm{xxx}$ & & $\mathrm{xx}$ & $\mathrm{xx}$ \\
\hline Ribes rubrum var. rubrum & red currant & & & & $\mathrm{xxx}$ & $\mathrm{xxx}$ & & & & & $\mathrm{xxx}$ & $\mathrm{x}$ \\
\hline Ribes spicatum & downy currant & & & & & & & & & & $\mathrm{xxx}$ & \\
\hline Rosa agrestis & small-leaved sweet-briar & & & & & & & & & & & $\mathrm{xxx}$ \\
\hline Rosa arvensis & field-rose & & & & & & & & & & & $\mathrm{xx}$ \\
\hline Rosa caesia & hairy dog-rose & & $?$ & & & & $\mathrm{xxx}$ & $\mathrm{xxx}$ & & $\mathrm{xxx}$ & & \\
\hline Rosa $\mathrm{x}$ gremlii & Rosa micrantha $\mathrm{x}$ Rosa rubiginosa & & $\mathrm{xxx}$ & & $\mathrm{xxx}$ & $\mathrm{xx} ?$ & $\mathrm{x}$ & $\mathrm{xxx}$ & & $\mathrm{xxx}$ & & $\mathrm{xx}$ \\
\hline Rosa vosagiaca & glaucous dog-rose & $\mathrm{xxx}$ & $\mathrm{xxx}$ & $\mathrm{xxx}$ & $?$ & $?$ & $\mathrm{xxx}$ & $\mathrm{xxx}$ & & $\mathrm{xxx}$ & & $?$ \\
\hline Rosa elliptica & wedge-leaved rose & & & & & & $\mathrm{xxx}$ & & & & & \\
\hline Rosa $\mathrm{x}$ inodora & Rosa agrestis $\mathrm{x}$ Rosa elliptica & & $\mathrm{xxx}$ & & & & $\mathrm{xxx}$ & $\mathrm{xxx}$ & & $\mathrm{xxx}$ & & $\mathrm{xxx}$ \\
\hline Rosa micrantha & small-flowered sweet-briar & & $\mathrm{xxx}$ & & $\mathrm{xxx}$ & $\mathrm{xxx}$ & $\mathrm{xxx}$ & $\mathrm{xxx}$ & & $\mathrm{xxx}$ & & $\mathrm{xxx}$ \\
\hline Rosa $\mathrm{x}$ suberectiformis & Rosa sherardii x Rosa tomentosa & & $\mathrm{xx}$ & & $\mathrm{x}$ & & $\mathrm{x}$ & & & & & \\
\hline Rosa rubiginosa & sweet-briar & $\mathrm{xxx}$ & $\mathrm{xxx}$ & $?$ & $?$ & $?$ & $\mathrm{x}$ & $\mathrm{x}$ & & $\mathrm{xxx}$ & & $\mathrm{xx}$ \\
\hline
\end{tabular}




\begin{tabular}{|c|c|c|c|c|c|c|c|c|c|c|c|}
\hline Rosa sherardii & Sherard's downy-rose & $\mathrm{xxx}$ & & & & $\mathrm{xxx}$ & & & & & \\
\hline Rosa spinosissima & burnet rose & $\mathrm{x}$ & & & & $\mathrm{x}$ & $\mathrm{x}$ & & & & \\
\hline Rosa x subcanina & Rosa canina x Rosa vosagiaca & $?$ & $?$ & $?$ & $?$ & $\mathrm{xxx}$ & $\mathrm{xxx}$ & $\mathrm{xxx}$ & $\mathrm{xxx}$ & & \\
\hline Rosa $\mathrm{x}$ subcollina & Rosa caesia x Rosa canina or $R$. corymbifera & $?$ & & $?$ & $?$ & $\mathrm{xxx}$ & $\mathrm{xxx}$ & & $\mathrm{xxx}$ & & \\
\hline Rosa tomentosa & harsh downy-rose & $\mathrm{xxx}$ & $\mathrm{xxx}$ & $\mathrm{xxx}$ & $\mathrm{xxx}$ & $\mathrm{xxx}$ & & & $\mathrm{xxx}$ & $\mathrm{xxx}$ & $\mathrm{xxx}$ \\
\hline Salix euxina & Eastern crack-willow & & & $\mathrm{x} ?$ & & & & & & & $\mathrm{x} ?$ \\
\hline Salix pentandra & bay-willow & $\mathrm{xxx}$ & $\mathrm{xxx}$ & $\mathrm{xxx}$ & & & & & & & \\
\hline Salix purpurea & purple willow & & & $\mathrm{xxx}$ & $\mathrm{xxx}$ & & $\mathrm{xxx}$ & $\mathrm{xxx}$ & & $\mathrm{xx}$ & $\mathrm{xxx}$ \\
\hline Sambucus racemosa & red-berried elder & & & & $?$ & & & & & & $\mathrm{xx}$ \\
\hline Taxus baccata & yew & & & $?$ & $\mathrm{xxx}$ & & & & & & \\
\hline Tilia cordata & small-leaved lime & & & $\mathrm{xxx}$ & $\mathrm{xxx}$ & & & & & $\mathrm{xxx}$ & $\mathrm{xx}$ \\
\hline Tilia $\mathrm{x}$ europaea & $\begin{array}{l}\text { European lime (Tilia cordata x Tilia } \\
\text { platyphyllos) }\end{array}$ & & & & & & & & & & $\mathrm{xxx}$ \\
\hline Tilia platyphyllos subsp. cordifolia & large-leaved lime (subsp.) & & & & $?$ & & & & & & $\mathrm{xxx}$ \\
\hline Tilia platyphyllos subsp. platyphyllos & large-leaved lime (subsp.) & & & & & & & & & & $\mathrm{xxx}$ \\
\hline Ulex europaeus & gorse & & & $?$ & $\mathrm{x}$ & & & & & $?$ & $?$ \\
\hline Ulmus glabra & wych elm & & & $\mathrm{x}$ & $\mathrm{x}$ & & & & & & $\mathrm{x}$ \\
\hline Ulmus laevis & European white-elm & & $\mathrm{x}$ & $\mathrm{x}$ & $\mathrm{x}$ & & & & & $\mathrm{x}$ & $\mathrm{x}$ \\
\hline Viburnum lantana & wayfaring-tree & & & & & & & & & & $?$ \\
\hline
\end{tabular}




\section{Two illustrative ancient forest woodlands: Elspeterbos and Savelsbos.}

I here discuss two examples of ancient woodlands extensively surveyed for the presence of autochthonous trees and shrubs using the method outlined above. As discussed, this additional knowledge on truly wild indigenous woody species leads to a better understanding of the forest vegetation, allowing better decisions to be made when it comes to management. This is of particular importance for Natura 2000 forests and woodlands. As these two case studies show, knowledge of prior history is indispensable.

\section{Elspeterbos}

Elspeterbos is one of the Netherlands' largest contiguous area of ancient forest [18]. It lies on the flank of a lateral moraine formed during the penultimate Ice Age, in a wider area known as the Veluwe, in the middle of the country. Neolithic farmers settled here around $5000 \mathrm{BC}$, and Neolithic and Bronze Age burial mounds are still to be seen in some parts of the forest. Until the late $20^{\text {th }}$ century the moraine forests remained an important source of timber, bark for the tanning industry and charcoal for iron production, as well as popular hunting grounds. By medieval times the vast forested areas were being managed collectively by villagers, as 'commons' (Fig. 5). So, too, in the village of Elspeet, where farmers managed their fields and forests as a communal undertaking. To guarantee wise use of the forest, detailed rules were drawn up to protect this valuable resource and ensure fair distribution of its products. Harvesting and sale of trees, branches, deadwood, acorns, beechnuts, forest berries and game were all recorded. Such commons were found throughout north-western Europe. The Elspeterbos records and transactions, preserved from the late $16^{\text {th }}$ century onwards, have only recently been studied and analysed in detail [19]. In 1917 the commons era came to an end and the forest was sold to a private land-owner, who did maintain public access to the forest, however.

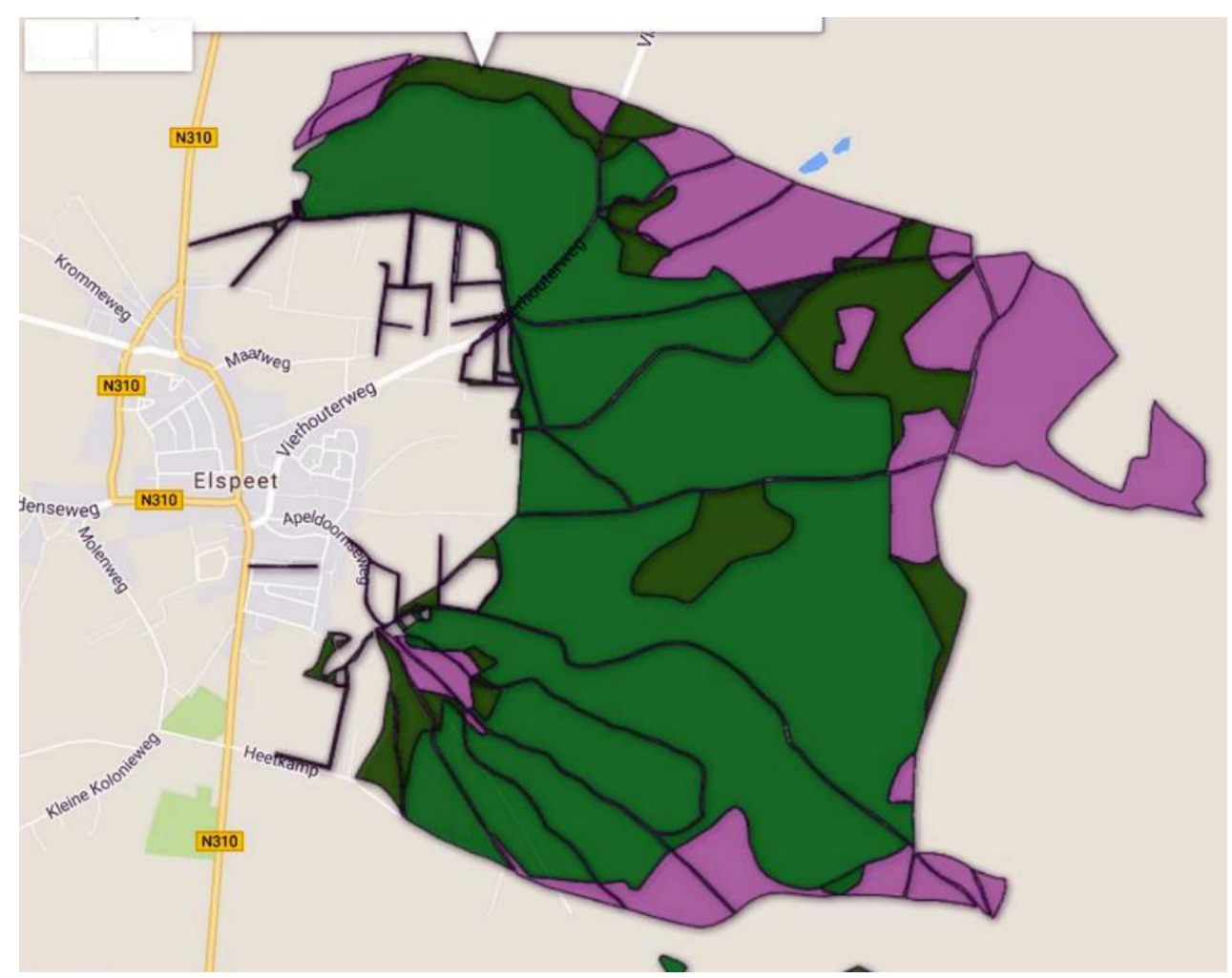

Fig. 5: Land registry map of Elspeterbos from 1832 (ancient woodland in green) 
Elspeterbos is a designated Natura 2000 area just over 500 hectares in size, half of which can be classed as ancient forest (Fig. 6). With its old, contorted beeches, it has an other-worldly feel to it. Locals call it 'the dancing-tree forest'. On further inspection there also prove to be numerous oaks, both pedunculate and sessile (Quercus robur, Q. petraea) as well as their spontaneous hybrid (Quercus x rosacea).

Interspersed between the tall trunks grow holly (Ilex aquifolia), rowan (Sorbus aucuparia), alder buckthorn (Rhamnus frangula), silver and downy birch (Betula pendula, B. pubescens) and honeysuckle (Lonicera periclymenum). Along the margins are numerous species of bramble, including Rubus phoenicacanthus, $R$. foliosus, $R$. grisiae, $R$. divaricatus, $R$. affinis, $R$. plicatus, $R$. geniculatus, $R$. scissus, $R$. sprengelii, $R$. integribasis, $R$. rubrum-cadaver and $R$. nemoripetens. The last of these species was only recently discovered. Like the shrub layer, the herb layer is sparse because of the shade created by the old beeches, the poorly decomposing beech and oak litter and the large game populations of roe deer, red deer and wild boar. The herb layer comprises little more than wavy hair-grass (Deschampsia flexuosa), foxglove (Digitaria purpurea) and a few ancientwoodland indicators like May lily (Maianthemum bifolium), wood sorrel (Oxalis acetosella) and bracken. The beech-oak woodland is established on a moder podzol soil, grading along the margins to heath-podzol.

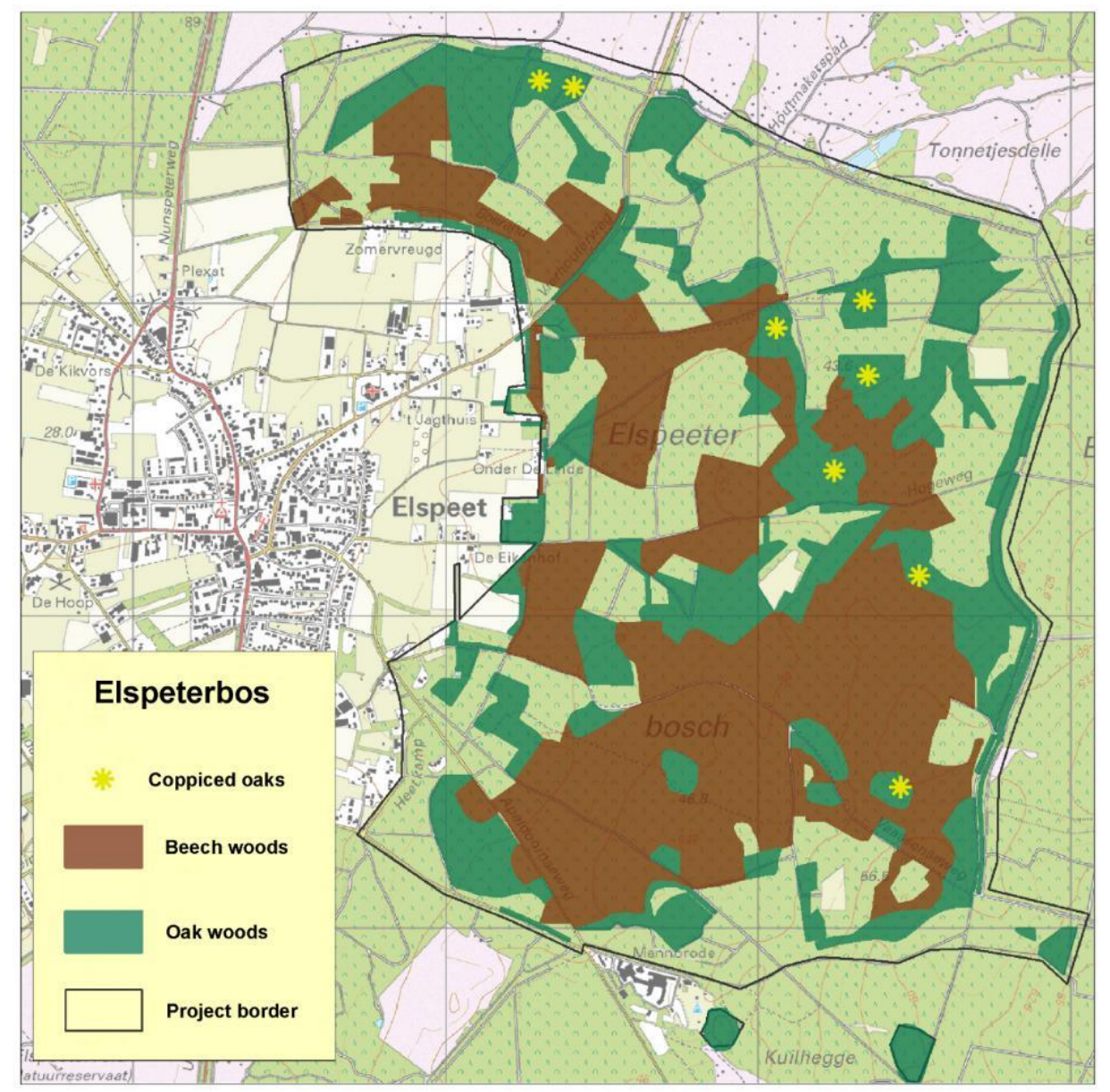

Fig 6: Distribution of current Elspeterbos woodlands dominated by either beech (Fagus sylvatica) or oaks (Quercus robur, Q. petraea) 
Pedunculate oak is the commonest oak, though in some parts of the forest sessile oak is locally numerous. A noteworthy feature are the trees with intermediate characteristics: hybrid oaks. In fact there is a wide spectrum of transitional forms between the two species.

Sessile oak and hybrid oak are often to be found in clusters, both large and small, probably defined by soil conditions. This points to the forest being very natural as well as of great age. Sessile oak is choosier than pedunculate oak and prefers loamier soils [16]. In the more distant past there is unlikely to have been conscious selection of sessile or pedunculate oak as a source of timber. More recently, from around 1900, there may have been a preference for pedunculate oak as sowing and planting stock because of its larger acorns.

While the oaks produce numerous saplings, it is striking that these seldom develop into shrubs or fully-grown trees, mainly because of the abundant shade. The mature oaks have developed from coppiced trees gradually reduced to single stems from the late $19^{\text {th }}$ century onwards (Fig. 7). When one of these old oaks is blown over by a storm, the contorted trunk foot reveals the coppicing history. Scattered through the forest are small sections with trees that today are still coppiced, mainly to provide cover for game. With their multiple stems and splayed-out foot, many of the older beeches also show signs of coppicing. It can be concluded that Elspeterbos was for centuries managed as 'coppice with standards': coppiced beech and oak interspersed with single-trunk standards of the same two species (Fig. 7). The Netherlands' Registry of Tree Varieties [1] lists the forest as a key site for both beech and pedunculate oak. For its beeches, the European Forest Genetic Resources Programme EUFORGEN has designated it a 'genetic conservation unit'. An important part of forest management is the exemption of sessile oaks, which are rare by Dutch standards.

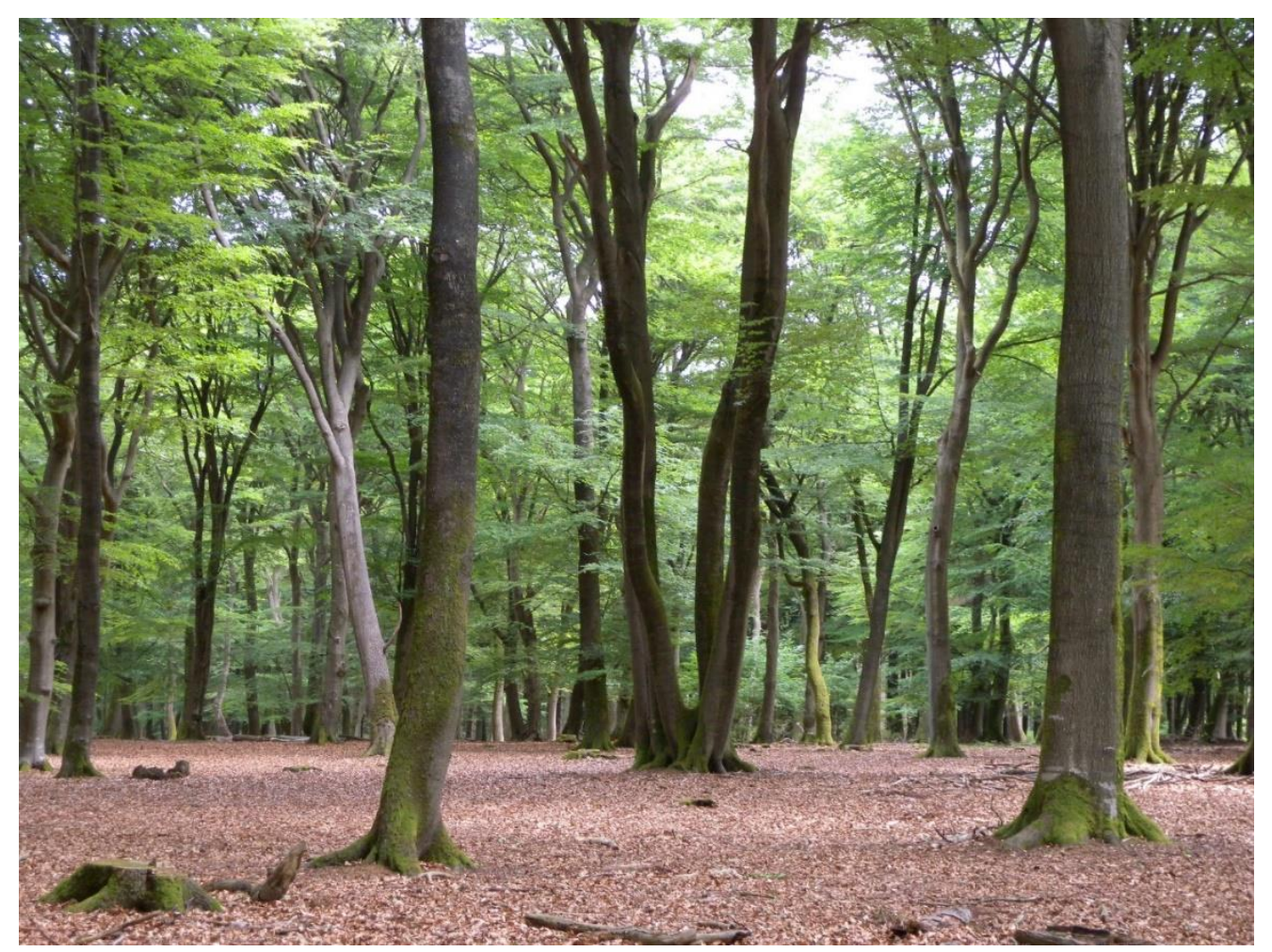

Fig. 7: Typical structure of the Elspeterbos woods with remains of coppiced beech and oak trees 


\section{Savelsbos}

In terms of the naturalness of its tree and shrub layer, Savelsbos, in the south of the Netherlands near the town of Maastricht, is the country's best preserved tract of ancient woodland [9]. It has a total area of around 240 hectares, about half of which can be classed as ancient woodland (Fig. 8). It is situated on the edge of a loess soil plateau, with flint-studded limestone exposed on parts of the slope. The Dutch limestone district is the northern edge of similar areas in Germany and Belgium. The slope on which much of Savelsbos is located was carved out many millennia ago by the River Maas. The fairly narrow woodland on the sloping terrain is dominated by lime-trees (Tilia spp.), merging into sessile oak woodland on the plateau itself. Characteristic features include two ravines perpendicular to the slope: so-called dry valleys that for centuries served as 'holloways' and outflows after heavy rainfall. Like Elspeterbos, the forest is undoubtedly ancient, though moulded by countless centuries of human intervention. A unique feature of Savelsbos are the subterranean Neolithic flint mines.

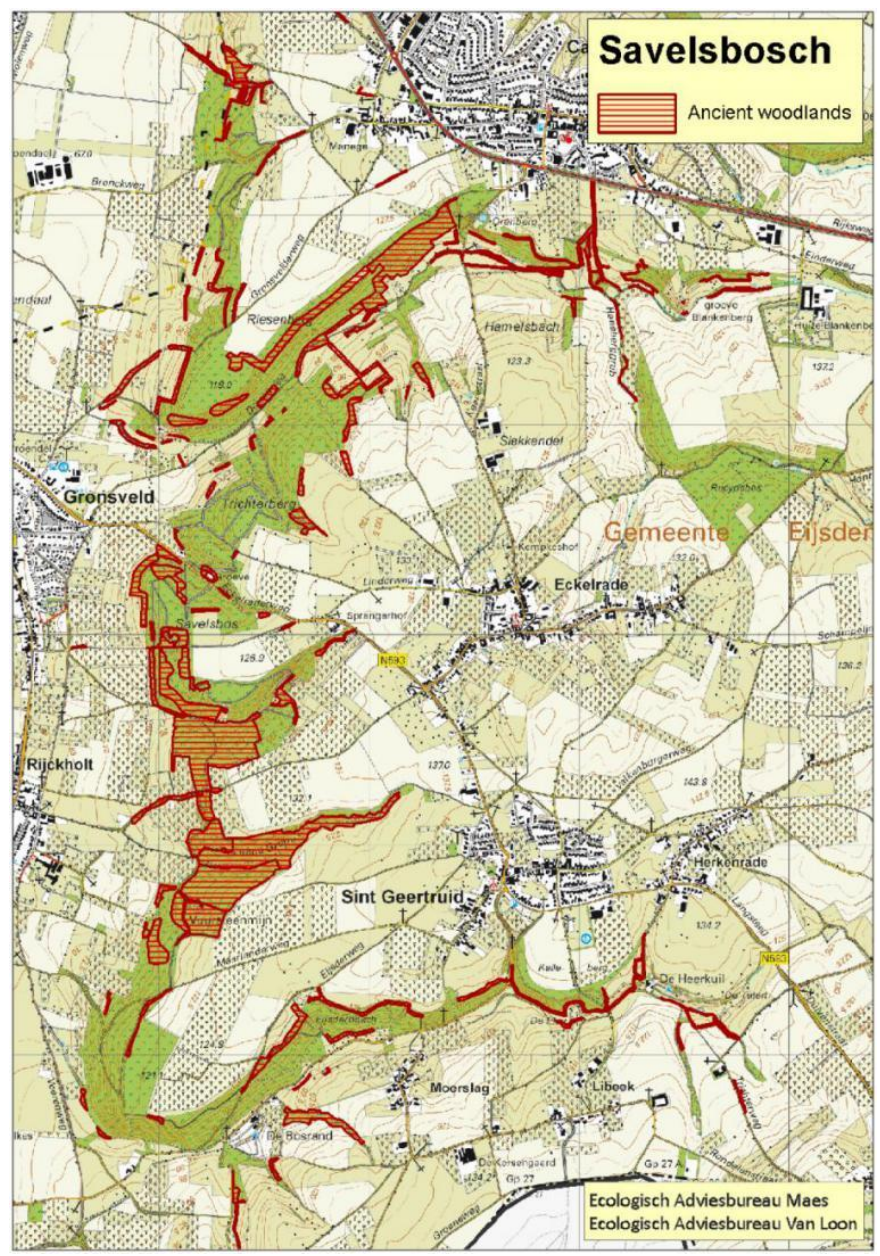

Fig. 8: Distribution of the current Savelsbos ancient woodlands (brown hatched areas).

The most striking tree species occurring in this forest are small-leaved and large-leaved lime (Tilia cordata, T. platyphyllos) (Fig. 9), though these are accompanied by some forty other autochthonous woody species, including field maple (Acer campestre), sycamore, ash (Fraxinus excelsior), European white-elm, small-leaved elm (Ulmus minor), silver birch, hornbeam (Carpinus betulus), cornelian cherry, barberry (Berberis vulgaris), wild red current (Ribes rubrum 
var. rubrum) and several kinds of wild rose (Rosa spp.) and hawthorn (Crataegus spp.). In this part of the Netherlands sycamore (Acer pseudoplatanus) and cornelian cherry (Cornus mas) are at the northern limit of their natural range. The central part of the woodland harbours around 3,000 limes, coppiced trees left essentially untouched since about 1950 and allowed to develop into 'high forest'. Many of the trees now stand 30 or more metres tall. Most of the other woody species, like hornbeam, field maple, silver birch, ash and sycamore, likewise have a coppicing history.

Of the two lime species, small-leaved is more prevalent. Large-leaved lime is represented by two subspecies: Tilia platyphyllos subsp. cordifolia and subsp. platyphyllos [15]. There are also a small number of spontaneous, wild hybrids: Tilia $\mathrm{x}$ europaea, the only specimens known in the country (see Fig. 10). These are to be distinguished from the countless hybrid 'Dutch limes' planted throughout the Netherlands since the $16^{\text {th }}$ century, when Dutch tree nurseries began growing and trading them, exporting untold numbers to England, Scandinavia, the Baltic states, North Germany and Russia. Noteworthy is the presence of an extremely old hybrid lime with a girth of about 10 metres near the German city of Aachen (perhaps from the $13^{\text {th }}$ of $14^{\text {th }}$ century), not that far from Savelsbos, which is almost certainly of wild stock. It is also of interest that several $17^{\text {th }}$ century lime-trees planted on road forks and at chapels in the area around Savelsbos are large-leaved limes - of both subspecies. This suggests that saplings or seedlings were taken from the forest and planted as way-markers outside the villages.

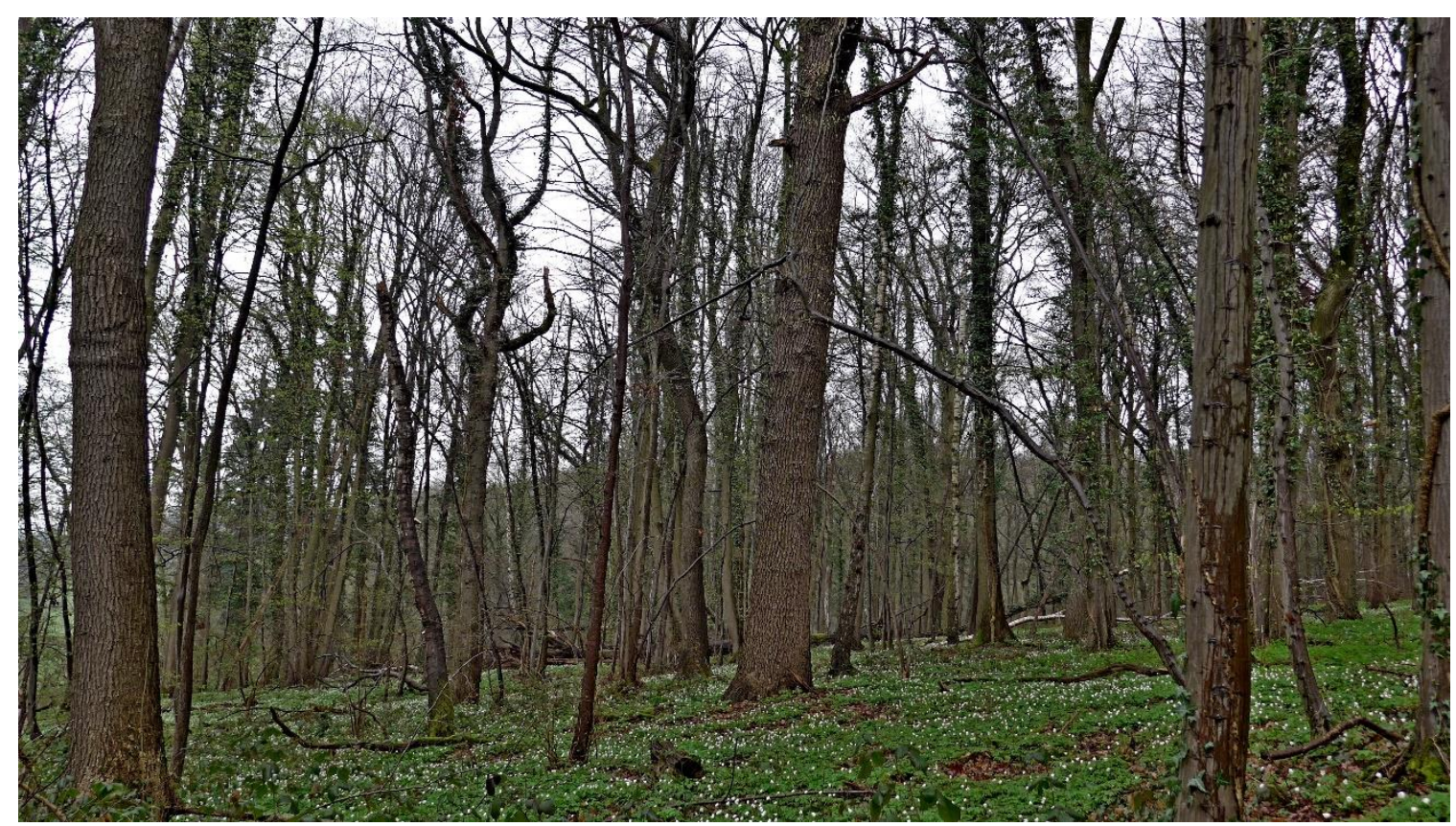

Fig. 9: Prevernal phenoaspect of mixed broadleaved woods of Savelsbos, featuring an abundant herb layer dominated by Anemone nemorosa (photo taken in April)

The herb layer in Savelsbos is especially rich and abundant, comprising numerous indicators ancient woodland [2]. Species recorded include wood anemone, yellow anemone (Anemone ranunculoides), black rampion (Phyteuma nigra), dog's mercury (Mercurialis perennis), wood spurge (Euphorbia amygdaloides), oxlip (Primula elatior), early dog-violet (Viola reichenbachiana), wild garlic (Allium ursinum), herb paris (Paris quadrifolia), woodland ragwort (Senecio ovatus), woodruff (Galium odoratum), wood melick (Melica nutans), greater butterfly- 
orchid (Plantanthera chlorantha), common twayblade (Neottia ovata), wood sedge (Carex sylvatica), hard shield-fern (Polystichum aculeatum) and hart's-tongue fern (Asplenium scolopendrium).

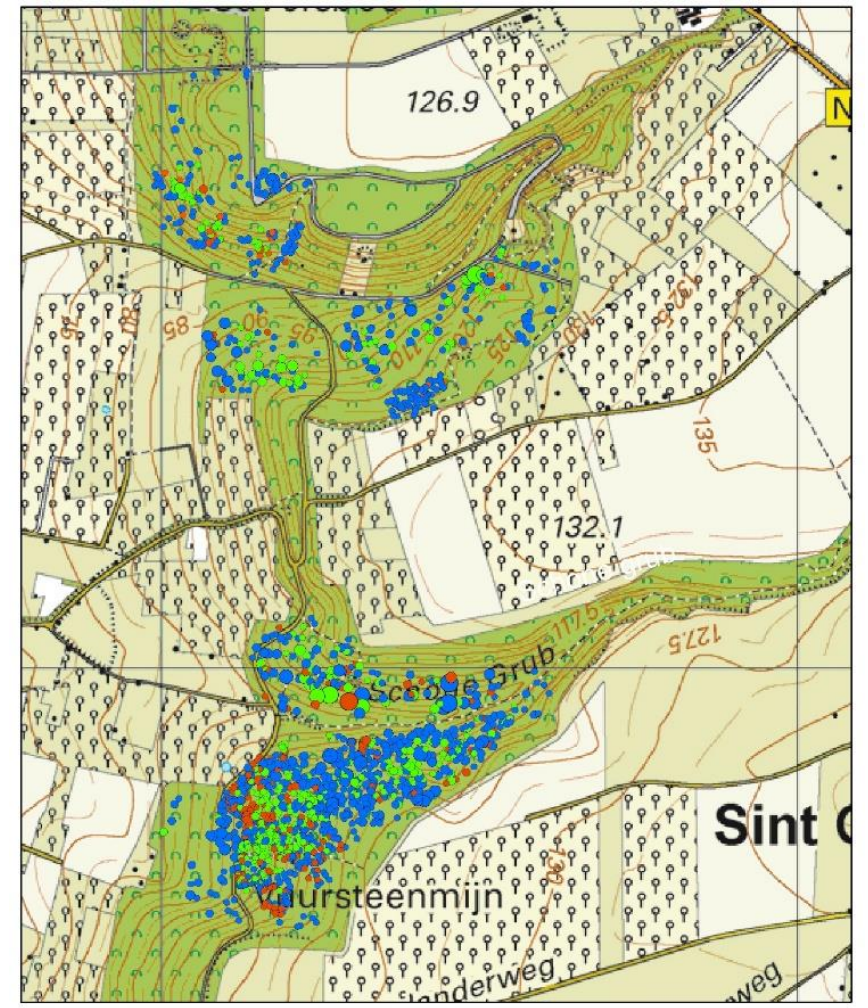

Fig. 10: Distribution of the lime trees in Savelsbos woodlands (blue - Tilia cordata; greenTilia platyphyllos; red - autochthonous Tilia $x$ europaea)

\section{Ancient woodland management and conservation in the Netherlands}

Both these Natura 2000 forests have a very long history, all the way back to the Neolithic, with many of the developments that have taken place over the centuries leaving marks still visible today. In both cases archives have been preserved, those of the moraine forest from the late $16^{\text {th }}$ century onwards. Coppicing and coppice-with-standards, the principal forms of traditional management, were discontinued in part during the $19^{\text {th }}$ century but mainly after about 1950 . As a result, both Elspeterbos and Savelsbos are now predominantly 'high forest', with a more natural feel to them. While in many respects a great improvement, this is also adversely affecting lightloving species in both the herb and shrub layer. This means management efforts need to be specifically tailored to small-scale variations in local tree-cover and other vegetation. In Elspeterbos the sessile and pedunculate oaks are both suffering and beginning to die back as the dominant beeches reduce available light. In some areas there is now dedicated protection of sessile oak clusters. Further improvement of ecological qualities could be achieved through phased thinning of beeches to favour the oaks and conversion of forestry stands to wild stands. High game densities are slowing germination and rejuvenation of both trees and shrubs. In the case of Savelsbos, until now there has been insufficient focus on the uniquely natural array of trees and shrubs. Here, too, dwindling light levels are proving problematic for some of the rarer lightdemanding species. Once again, well-focused thinning would improve the situation. Increasing the 
numbers of rare species with too small populations is recommended as well. Given the combination of natural woodland and exotic planting in the past, the recommended course of action is to move towards a forest consisting solely of autochthonous woody species. In this regard, it is important that the correct species are used for new plantings and expansion of ancient woodland. Correct species belong to the habitat type and have the same genetic autochthonous origin as the ancient woodland. Unfortunately, using the correct species is often not the case in practice. So for example exotics such as silver fir (Abies alba) and Turkish hazel (Corylus colurna) were recently planted as part of forestry experiments on the borders of Savelsbos.

Agricultural fertilizer and pesticide use on adjacent land are among the other specific problems facing Natura 2000 forests and woodland. Measures to facilitate organic farming around these protected areas are therefore emphatically recommended. In the meantime, creating buffer zones is an urgent task. To secure Natura 2000 objectives in the Netherlands requires new understanding, new strategies and creativity and remains a major challenge for the agencies managing these irreplaceable forest sites.

\section{Conclusions}

In the Netherlands, autochthonous specimens of many species of indigenous trees and shrubs are now rare, as are relics of ancient woodland, hedgerows and wooded banks. In many places their continued vitality is under threat; moreover, on the one hand from intensive agriculture, on the other from a lack of knowledge and experience with regard to management and conservation. Improvement of this situation is hampered by the Dutch interpretation of the Natura 2000 programme, which has no provisions for mandatory protection and management of wild trees and shrubs. The problem is further compounded by the mix of wild and non-wild woody species growing in what is generally viewed as 'natural woodland'.

Since 1990 we have been developing and applying a methodology to recognise such trees and shrubs on the basis of criteria relating to the woody species themselves and to where they are growing. The results for a large proportion of the Netherlands are available online and in this paper we present an overview of the rare and vulnerable species in each Dutch province. With reference to two examples of Dutch ancient woodlands, we discuss the nature and characteristics of the autochthonous tree and shrub layer as the basis of the forest biocoenosis, the problems identified and potential solutions. Key problems include the influence of deposition of agricultural fertilisers and pesticides, the discontinuation of coppicing and the resultant increase in shade, and the presence of non-wild trees and shrubs. To effectively conserve the Netherlands' autochthonous woody species, it is recommended that before forest management plans are drawn up, the tree and shrub layer is analysed in detail using the methodology described in this paper and that appropriate management strategies are elaborated based on that knowledge. Our methodology can, and in our view should be, applied more widely in the countries of north-western Europe.

As a final recommendation, we advise adopting internationally consistent terminology to distinguish truly wild specimens of indigenous woody species, e.g. autochthonous (in English), autochtone (in French), autochtoon (in Dutch), autochthon (in German). 


\section{REFERENCES}

1. Buiteveld, J., Helmink, T., de Vries, S., 2016, Identificatie van autochtone eikenpopulaties in Nederland: chloroplast DNA als hulpmiddel, De Levende Natuur, 117: 6-10.

2. Harle, N., 2014, Karakteristieke kruiden van het Savelsboscomplex. Verslag van een gedetailleerde kartering 2009-2013, Eigen uitgave voor Staatsbosbeheer, Gronsveld.

3. Kowarik, I., Seitz, B., 2003, Perspektiven für die Verwendung gebietseigener ('autochthoner') gehölze, Neobiota, 2: 1-116.

4. Lange, S., 2017, Uit het juiste hout gesneden. Houten gebruiksvoorwerpen uit archeologische context tot 1300 n.Chr. Nederlandsche Archeologische Rapporten 54, Rijksdienst voor het Cultureel Erfgoed, Amersfoort.

5. Lange, S., van der Laan, J., Nicolaij, S., 2019, Woodan, Archaeological wood database. https://www.woodan.org/.

6. Maes, B., 2016, Atlas van het landschappelijk groen erfgoed van Nederland, Netherlands Cultural Heritage Agency, Amersfoort (https://landschapinnederland.nl/kaart-groen-erfgoed).

7. Maes, N.C.M., (ed.), 2013, Inheemse bomen en struiken in Nederland en Vlaanderen, Boom, Amsterdam.

8. Maes, N.C.M., (ed.), 2021, Atlas wilde bomen en struiken. Landschappelijk groen erfgoed in de provincies van Nederland en Vlaanderen, Pictures Publishers, Woudrichem.

9. Maes, N.C.M., van Loon, R., 2013, Rapport Limburg. Inventarisatie autochtone bomen en struiken in de terreinen van Staatsbosbeheer, Staatsbosbeheer, Utrecht-Berg en Dal.

10. Maes, N.C.M., 1993, Genetische kwaliteit inheemse bomen en struiken, Deelproject: Randvoorwaarden en knelpunten bij behoud en toepassing van inheems genenmateriaal. IBN, Wageningen.

11. Maes, N.C.M., Rövekamp, C., Zwaenepoel, A., Cosyns, E., Opstaele, B., de Wettinck, H., 1996-2006, Several reports on ancient woodlands and wooded banks in Flanders, Belgium.

12. Ministry of Agriculture, Nature and Food Quality, 1998, Flora en Fauna wet, Bull Acts Decrees, No. 402, 1999, No. 264; last revisions: Bull. 2008, 4 and Government Gazette 2010, No. 20455. Den Haag.

13. Out, W.A., 2009, Sowing the seed? Human impact and plant subsistence in Dutch wetlands during the Late Mesolithic and Early and Middle Neolithic (5500-3400 c. BC), PhD thesis, Leiden University Press, Leiden.

14. Petit, R., Csaikl, U.M., Bordács, S., Burg, K., Coart, E., Cottrell, J., van Dam, B.C., Deans, J.D., DumolinLapogue, S., Fineschi, Finkeldey, R., Gillies, A., Glaz, I., Goicoechea, P.G., Jensen, J.S., König, A.O., Lowe, A.J., Madsen, S.F., Mátyás, G., Munro, R.C., Olalde, M., Pemonge, M.H., Popescu, F., Slade, D., Tabbener, H., Taurchini, D., de Vries, S.G.M., Ziegenhagen, B., Kremer, A., 2002, Chloroplast DNA variation in European white oaks phylogeography and patterns of diversity based on data from over 2600 populations, Forest Ecology and Management, 156: 5-26.

15. Pigott, C., 2012, Lime-trees and Basswoods. A Biological Monograph of the Genus Tilia, Cambridge University Press, Cambridge.

16. Prins, G.A.H., Maes, N.C.M., Smit, M.J.T.M., 1993, De wintereik in Nederland, Stichting Kritisch Bosbeheer, Wageningen.

17. Rackham, O., 2003, Ancient Woodland: Its History, Vegetation and Uses in England, 2nd edition, Castlepoint Press, Colfend, UK.

18. Rövekamp, C., Maes, N.C.M., 2002, Inheemse bomen en struiken op de Veluwe. Autochtone genenbronnen en oude bosplaatsen, WCL Veluwe, Provincie Gelderland, Arnhem.

19. Veen, P., Maes, N.C.M., van den Dool, E., 2017, Het Elspeterbos; Verleden, heden en toekomst van een historisch malenbos, Veen Ecology, Nunspeet.

\section{NOI PERSPECTIVE PRIVIND IDENTIFICAREA, MANAGEMENTUL ȘI CONSERVAREA ARBORILOR ȘI ARBUȘTILOR INDIGENI DIN OLANDA}

(Rezumat)

În țările europene dens populate, precum Olanda, elementele de peisaj vechi, cum sunt pădurile și gardurile vii, sunt rare. Din cauza introducerii speciilor exotice și a arborilor și arbuștilor importați din alte zone climatice, 
recunoaşterea indivizilor şi populațiilor cu adevărat autohtone este problematică, punând în dificultate agențiile silvice, mai ales în cazul siturilor Natura 2000. Autorul a dezvoltat o metodă de recunoaștere genetică a speciilor lemnoase pur sălbatice, pe baza caracteristicilor plantelor și a locului în care cresc. Această metodă, explicată aici, a fost aplicată pentru expertizarea a aproximativ $70 \%$ din teritoriul Olandei, mare parte a Flandrei şi o parte din regiunea inferioară a Rinului din Germania. Rezultatele obținute sunt exemplificate prin două zone vechi împădurite din Olanda, unde s-au obținut perspective noi în ceea ce privește statusul nativ al speciilor lemnoase și 'autenticitatea' straturilor arborescent și arbustiv.

Received: 16.07.2021; Accepted: 21.09.2021 